\title{
WHAT HAS ARISTOTLE TO DO WITH PAUL? RHETORICAL CRITICISM AND 1 THESSALONIANS
}

\author{
Steve Walton
}

\section{Summary}

This article considers the application of rhetorical critical methods to 1 Thessalonians, summarising the approaches of significant scholars before considering the rhetorical genre of the letter. After considering the options, a key issue is identified: the question of whether Paul faced opponents in the church at Thessalonica. The evidence favours a negative conclusion, and the rhetorical genre is concluded to be epideictic, because of the focus of the letter on praise and blame.

\section{Introduction}

In recent times a growing number of studies have appeared using the tools provided by rhetoric, both ancient and modern, to analyse and understand the biblical documents. ${ }^{1}$ In New Testament studies, Betz' work on Galatians launched this new era, ${ }^{2}$ followed by the highly influential work of Kennedy, ${ }^{3}$ who has provided a classicist's perspective to the development of the discipline.

\footnotetext{
${ }^{1}$ For an introduction to rhetorical criticism, see my article 'Rhetorical Criticism: An Introduction', forthcoming in Themelios.

${ }^{2}$ Hans Dieter Betz, 'The Literary Composition and Function of Paul's Letter to the Galatians', New Testament Studies 21 (1975) 353-79; Hans Dieter Betz, Galatians: A Commentary on Paul's Letter to the Churches in Galatia (Philadelphia: Fortress, 1979).

${ }^{3}$ George A. Kennedy, Classical Rhetoric and its Christian and Secular Tradition from Ancient to Modern Times (Chapel Hill: University of North Carolina Press, 1980); George A. Kennedy, New Testament Interpretation through Rhetorical Criticism (Chapel Hill: University of North Carolina Press, 1984).
} 
What these modern scholars are doing is not, of course, a new procedure. Fairweather draws attention to Chrysostom's use of rhetorical categories in his commentary of Galatians, ${ }^{4}$ as does Kennedy to Augustine working in similar manner (in On Christian Doctrine), 5 and Classen to Philip Melanchthon's use of rhetoric in his works on Biblical Studies. 6

This paper will outline recent rhetorical work on 1 Thessalonians, and consider issues in the study of 1 Thessalonians from a 'rhetorical' perspective, particularly the question of the rhetorical genre of the letter.

\section{Rhetorical Approaches to 1 Thessalonians}

Scholarly study of 1 Thessalonians moved in a rhetorical direction with an influential article by A. Malherbe, ${ }^{7}$ in which he argued that 1 Thessalonians 2:1-12 should be understood against the background of Dio Chrysostom's writings about the popular philosophers of his day, especially the Cynics. ${ }^{8}$ Whilst Malherbe's conclusions have been challenged, 9 the general approach he took, of attempting to understand Paul against the backcloth of other writers of his times, has been built upon.

4Janet Fairweather, 'The Epistle to the Galatians and Classical Rhetoric: Parts 1 \& 2', Tyndale Bulletin 45 (1994) 1-38, esp. 2-22.

${ }^{5}$ Kennedy, New Testament Interpretation, 11.

C. Joachim Classen, 'St Paul's Epistles and Ancient Greek and Roman Rhetoric', in Stanley E. Porter and Thomas H. Olbricht (eds.), Rhetoric and the New Testament: Essays from the 1992 Heidelberg Conference (Sheffield: JSOT Press, 1993) 265-91, esp. 271-79.

${ }^{7}$ Abraham J. Malherbe, "'Gentle as a Nurse": The Cynic Background to I Thess ii', Novum Testamentum 12 (1970) 203-17, building upon earlier work of Martin Dibelius, An die Thessalonicher I, II, an die Philipper (Tübingen: J.C.B. Mohr, 1937) 7-11 (cited in Malherbe, "'Gentle as a Nurse"', 203 n. 2). 8 Malherbe refers particularly to Dio Chrysostom Orations 32.

9See, for example, K.P. Donfried, "The Theology of 1 Thessalonians as a Reflection of its Purpose', in M.P. Horgan and P.J. Kobelski (eds.), To Touch the Text: Biblical and Related Studies in Honor of Joseph A. Fitzmyer, SJ (New York: Crossroad, 1989) 243-60, esp. 258-59; I. Howard Marshall, 1 and 2 Thessalonians (London: Marshall Morgan \& Scott, 1983) 61; Bruce W. Winter, 'Entries and Ethics of the Orators and Paul (1 Thessalonians 2:112)', TynB44 (1993) 55-74, esp. 73 n. 73. 
Malherbe has gone on to produce articles considering the parallels of 1 Thessalonians with hortatory devices and styles in the philosophers, concluding that Paul used recognisable styles, but reshaped them in theo- and christocentric fashion, 10 and arguing that 1 Thessalonians is a parænetic (or exhortatory) letter. ${ }^{11} \mathrm{He}$ has also argued, on the basis of the epistolary conventions of the period, that there is a high likelihood that Paul received a letter from the Thessalonian Christians, delivered by Timothy on his return from Thessalonica, and that Timothy may have delivered a brief letter from Paul to the Thessalonians on his visit. 12

Wuellner considers 1 Thessalonians as a 'paradoxical encomium'.$^{13}$ His presupposition is that more is to be gained from rhetorical analysis of the letter than traditional epistolary analysis. ${ }^{14}$

Jewett's The Thessalonian Correspondence represents one of the most full-blown attempts to use rhetorical categories to understand the letter (and 2 Thessalonians also). He argues that it is necessary to use rhetorical methods to identify the letter's audience, whereas classical use of rhetorical methods in New Testament studies has been to understand the author. ${ }^{15}$ Jewett uses the ancient rhetorical handbooks as one tool in his rhetorical-critical work on the letter, but prefers the possibilities

\footnotetext{
${ }^{10}$ Abraham J. Malherbe, 'Exhortation in First Thessalonians', Novum Testamentum 25 (1983) 238-56.

${ }^{11}$ Abraham J. Malherbe, 'Hellenistic Moralists and the New Testament', in Wolfgang Haase (ed.), Aufsteig und Niedergang der römischen Welt II, 26.1 (Berlin: de Gruyter, 1992) 267-333, esp. 278-93.

${ }^{12}$ Abraham J. Malherbe, 'Did the Thessalonians Write to Paul?', in R.T. Fortna and B.R. Gaventa (eds.), The Conversation Continues: Studies in Paul and John in Honor of J. Louis Martyn (Nashville: Abingdon, 1990) 246-57. These various articles are precursors to a major commentary on the Thessalonian letters by Malherbe in the Anchor Bible series.

13Wilhelm Wuellner, 'The Argumentative Structure of 1 Thessalonians as Paradoxical Encomium', in Raymond F. Collins (ed.), The Thessalonians Correspondence (Leuven: Leuven University Press, 1990) 117-36.

${ }^{14}$ Wuellner, 'The Argumentative Structure', 117.

${ }_{15}^{15}$ Robert Jewett, The Thessalonian Correspondence: Pauline Rhetoric and Millenarian Piety (Philadelphia: Fortress, 1986) 63.
} 
offered by the 'New Rhetoric', on the grounds that they 'offer a more comprehensive account of epistolary communication'.16

Subsequent to Jewett, Johanson has developed a model of rhetorical analysis which utilises insights from linguistics alongside ancient and modern rhetorical categories, aiming at an understanding of 1 Thessalonians as an 'act of communication'.17 Johanson is cautious of the use of Aristotelian rhetorical categories in studying a Pauline letter, on the grounds both that the three classical genres (epideictic, deliberative and judicial [or forensic]) were defined at a time before sermons were common; and also that it is questionable whether any Pauline letter can be classified simply in one genre, since:

While forensic, deliberative and epideictic characteristics may appear more or less prominently...depending on the particular exigence(s) occasioning Paul's letters, it is doubtful whether any of them can be adequate generic categories strait [sic] across the board. 18

Accordingly, Johanson is critical of Kennedy, ${ }^{19}$ whom he sees as falling into precisely this trap.

Other recent approaches to 1 Thessalonians utilising a rhetorical standpoint include the work of Olbricht, ${ }^{20}$ Hughes, ${ }^{21}$

\footnotetext{
16Jewett, The Thessalonian Correspondence, 64 .

17Bruce C. Johanson, To All the Brethren: A Text-Linguistic and Rhetorical Approach to 1 Thessalonians (Uppsala: Almqvist \& Wiksell International, 1987) 3.

Johanson, To All the Brethren, 41.

${ }^{19}$ Kennedy, New Testament Interpretation, esp. 19: 'There are three species of rhetoric...judicial, deliberative, and epideictic. Although these categories specifically refer to the circumstances of classical civic oratory, they are in fact applicable to all discourse.' (italics his).

${ }^{20}$ Thomas H. Olbricht, 'An Aristotelian Rhetorical Analysis of 1 Thessalonians', in David L. Balch, Everett Ferguson and Wayne A. Meeks (eds.), Greeks, Romans and Christians: Essays in Honor of Abraham J. Malherbe (Minneapolis: Fortress, 1990) 216-236.

21F.W. Hughes, 'The Rhetoric of 1 Thessalonians', in Raymond F. Collins (ed.), The Thessalonian Correspondence (Leuven: Leuven University Press, 1990) 94-116.
} 
Winter, ${ }^{22}$ Donfried 23 and the major commentary of Wanamaker. ${ }^{24}$

In the light of our discussion so far, we turn to consider questions in the study of 1 Thessalonians where rhetorical criticism may have insights to offer.

\section{The Rhetorical Genre of 1 Thessalonians}

Four main answers have been given to the question of the rhetorical genre of 1 Thessalonians. We shall examine these in turn, noting the arguments adduced for each position, and then highlight outstanding questions that result from the discussion.

\section{Deliberative}

Deliberative rhetoric focuses on a decision about the future: a speaker delivering a deliberative speech has the aim of persuading the audience to follow a certain course of action.

Kennedy argues that 1 Thessalonians should be seen as deliberative because the main focus is 3:8: 'since you are

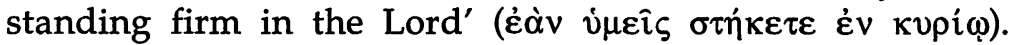
Accordingly, Kennedy sees the whole letter as an exhortation to stand fast in the Lord, combined with specific advice on the Christian life. ${ }^{25}$ Therefore in the narratio in 1 Thessalonians 2-3 Paul is establishing his ethos, rather than the presence of narrative being a sign of judicial rhetoric. Kennedy believes that Paul is being criticised in Thessalonica, seeing 2:1-8 as a refutation of charges against him. Accordingly Paul attempts to identify himself with the church at Thessalonica and to stress the continuity of their relationship, for example by the emphasising terms in 1:2: 'We thank God always for you all,

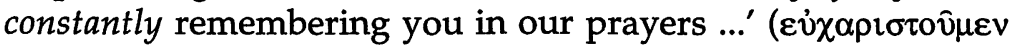

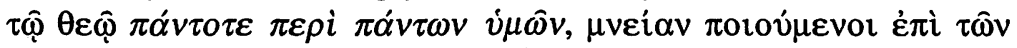
$\pi \rho \circ \sigma \varepsilon v \chi \hat{\omega} v \dot{\eta} \mu \hat{\omega} v, \dot{\alpha} \delta \imath \alpha \lambda \varepsilon i \pi \tau \omega \varsigma$, italics mine).

\footnotetext{
22Winter, 'Entries and Ethics'.

${ }^{23}$ Karl P. Donfried and I. Howard Marshall, The Theology of the Shorter Pauline Letters (Cambridge: CUP, 1993) 1-79.

${ }^{24}$ Charles A. Wanamaker, The Epistles to the Thessalonians (Grand Rapids/Exeter: Eerdmans/Paternoster, 1990).

25Kennedy, New Testament Interpretation, 142.
} 
Johanson sees the main focus of the letter as consolation, principally in response to the death of believers, which he considers to be the main exigence of the letter. ${ }^{26}$ Therefore he argues that deliberative is the best description of the genre, 'a delicate combination of consolation and correction without reproof' ${ }^{27} \mathrm{He}$ further claims that the style of the Christological proofs in 4:14; 5:9-10 is deliberative, ${ }^{28}$ and that the remarks of Aristotle on narratio in deliberative oratory show 'striking parallels...to the exordial-narrative character of I Thess $1-3^{\prime} .29$ Johanson concedes that the concerns of the letter are not those of standard (classical) deliberative rhetoric, that is political expediency, 'but rather with the spiritual questions of truth and salvation' .30 We shall return to the question as to whether this difference means that the letter ought to be seen as lying outside the usual categories of rhetoric.

\section{Epideictic}

The most widely-canvassed option is that 1 Thessalonians should be seen as epideictic. The major reason offered for this is that a characteristic of epideictic rhetoric is the focus on praise and blame, with the aim of persuading the readers to reaffirm or maintain a point of view in the present. Jewett cites pseudoDemetrius and pseudo-Libanius, who both discuss a style of letter called the 'thankful letter'. ${ }^{31}$ Jewett argues that this is compatible with the view taken of the purpose and character of

26Johanson, To All the Brethren, 165-66.

27Johanson, To All the Brethren, 189.

28Johanson, To All the Brethren, 166. He argues on the basis of Berger's description of 'symbuleutischer Argumentation' in Klaus Berger, 'Hellenistische Gattungen im Neuen Testament', in Wolfgang Haase (ed.), Aufstieg und Niedergang der römischen Welt II, 25.2 (Berlin/New York: de Gruyter, 1984) 1148. However, Berger does not cite any of the 1 Thessalonians texts as examples of deliberative rhetoric, and only mentions 'christologische Begründungen' as one characteristic of deliberative.

29Johanson, To All the Brethren, 166. He cites Aristotle Rhetoric 3.16.11, but see discussion of this passage below.

30Johanson, To All the Brethren, 166.

31Jewett, The Thessalonian Correspondence, 71-72. The texts can be found in Abraham J. Malherbe, Ancient Epistolary Theorists (Atlanta: Scholars Press, 1988) $40-41,68-69$. 
1 Thessalonians in many of the standard commentaries, citing Moffatt, Marxsen, Marshall and Koester as examples. 32

Hughes likewise sees the focus on praise and blame as a key mark of epideictic rhetoric and finds such material in the letter. ${ }^{33} \mathrm{He}$ further claims that the use of epideictic rhetoric fits with Paul's intention to strengthen an existing relationship. ${ }^{34}$ He believes that the letter contains no Pauline self-defence, which makes it unlikely that the letter should be seen as judicial; and that the letter is not advocating a change of policy in the future, which makes it unlikely that the letter should be seen as deliberative. The latter is a telling criticism of the above view of Kennedy.

Wuellner's view seems close to those of Jewett and Hughes. He considers that the letter should be identified with a sub-type of the epideictic genre, the paradoxon enkomion, citing the use of rhetorical figures suitable for that genre, namely irony, paradox and oxymoron. ${ }^{35}$

Lyons, who identifies the focus of the letter as parænesis, believes that the exhortation being offered is epideictic. ${ }^{36}$ He cites Dionysius of Halicarnassus, who saw parænesis as a sub-type of the epideictic genre, but equally observes that amongst the rhetors exhortation could be present in deliberative rhetoric also. ${ }^{37} \mathrm{He}$ prefers epideictic as a description because of the presence of thanksgiving in 1 Thessalonians 1-3, which he considers to be a definite mark of epideictic. Further, the 'lack of intensity' in Paul's exhortations implies that he is pleased with their progress and is writing to encourage them to continue along a course that they are already pursuing.

32Jewett, The Thessalonian Correspondence, 72.

${ }^{33}$ Hughes, 'The Rhetoric of 1 Thessalonians', 97.

${ }^{34}$ Hughes, 'The Rhetoric of 1 Thessalonians', 106.

35Wuellner, 'The Argumentative Structure', 123, 126-27.

36 George Lyons, Pauline Autobiography: Towards a New Understanding (Atlanta: Scholars Press, 1985) 219-21.

${ }^{37}$ Lyons, Pauline Autobiography, 220, in dependence on Theodore Chalon Burgess, Epideictic Literature (Chicago: University of Chicago Press, 1902) 112-13, 231-32, who cites Dionysius of Halicarnassus Mé $\theta 0 \delta$ os غ̇ $\pi \imath \theta \alpha \lambda \alpha \mu i \omega v$ sec. 3 (= Ars rhetorica 4.3 ): 'with praise mingle advice' (presumably as a

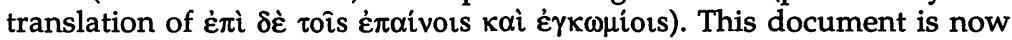
generally considered spurious and likely to be third century AD. 
Recently, Donfried has also argued that 1 Thessalonians should be seen as epideictic, principally because of the letter's focus on praise (e.g. 2:1-12) and blame (e.g. 2:14-16). ${ }^{38} \mathrm{He}$ criticises the view that the letter should be seen as forensic on the grounds that there are no 'explicit and sustained charges against Paul' 39 , especially in 2:1-12. We shall consider this further below in discussing the question whether there were opponents of Paul in Thessalonica.

\section{Parænesis}

We have noticed Lyons' belief that exhortation is the focus of 1 Thessalonians, and some scholars seem to believe that this should be seen as the genre of the letter in its entirety. In his survey of types of ancient letter, Stowers states his conclusion that 1 Thessalonians is parænetic, without giving reasons beyond defining the parænetic type of letter as coming from a friend or moral superior and recommending habits of life for the furtherance of certain models of character (and the avoidance of other errors). 40

The major pieces of work arguing this conclusion are those of Malherbe. He propounds the view that, as well as 4:15:22 being parænetic, which is generally accepted, the introductory thanksgiving (1:2-3:13) should also be seen this way. ${ }^{41}$ In particular, he draws attention to the philophronetic character of 2:17-3:13, paralleling it to the letter of friendship in (pseudo-)Demetrius, $\mathbf{4 2}$ but arguing that the philophronetic character of the section does not mean that it is not parænetic. He notices the presence of 'you know' (oind $\alpha \tau$ ) twice in 3:3-4which he believes to be characteristic of parænesis-as evidence of the parænetic character of the section. He summarises in writing:

I Thessalonians 1-3 thus exhibits the characteristics of a parænetic letter. The description of the readers as $\mu \iota \mu \eta \tau \alpha^{i}$

38Donfried \& Marshall, The Theology of the Shorter Pauline Letters, 3-5.

${ }^{39} \mathrm{Ibid}, 5$.

${ }^{40}$ Stanley K. Stowers, Letter-Writing in Greco-Roman Antiquity (Philadelphia: Westminster Press, 1986) 96.

41Malherbe, 'Hellenistic Moralists and the New Testament', 279-80.

42Ibid, 291-92, 
['imitators'], the theme of remembrance of what is already

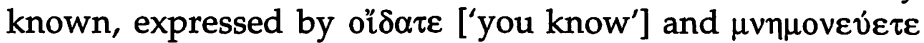
['remember'], the description of Paul himself in antithetical style, the theme of philophronesis, all contribute to this conclusion. 43

Aune argues that the concluding 'hortatory' section is the main part of the letter (i.e. 4:1-5:22). $44 \mathrm{He}$ follows Malherbe in believing that Paul in the letter exhibits two specifically parænetic styles, namely moral exhortation and antithesis. 45 Aune does not see the antithetical style, such as in 2:1ff, as the result of criticisms of Paul, but rather as a technique used to expatiate upon a topic by using contrasting ideas to clarify the positive points being made. 46 Further, Aune cites the emphasis upon reminder (e.g. 1:5; 2:1-10) as another characteristic of parænesis.

Marshall notices the presence of exhortation and teaching in 1 Thessalonians 4:5,47 but also observes, "The whole letter is a masterly piece of pastoral encouragement based on the existing progress made by the readers' ${ }^{48}$ Marshall does not explicitly tackle the question of the rhetorical genre of the letter. Since he wrote in days before rhetorical-critical studies became widespread, he may therefore not belong within this group.

All this said, none of the scholars mentioned appears to address the question of what kind of exhortation is being

Malherbe, 'Hellenistic Moralists and the New Testament', 292. Boers concurs with Malherbe's conclusion, having rejected the authenticity of 2:13-16, a path down which Malherbe does not go (Hendrikus Boers, "The Form-Critical Study of Paul's Letters: 1 Thessalonians as a Case Study', New Testament Studies 22 (1975-76) 140-58, esp. 158; cf. Malherbe, 'Hellenistic Moralists and the New Testament', 290, esp. n. 109).

${ }^{44}$ David E. Aune, The New Testament in its Literary Environment (Cambridge: James Clarke, 1988) 206.

${ }^{45}$ Malherbe, 'Exhortation in First Thessalonians'; Malherbe, 'Hellenistic Moralists and the New Testament', esp. 290.

${ }^{46}$ Aune, The New Testament in its Literary Environment, 206 cites as examples Aristotle Rhetoric 1409b-1410a (=3.9.3-8); Pseudo-Aristotle Rhetoric to Alexander 1435b (= 26); Hermogenes On Invention 4.2 ( $\pi \varepsilon \rho i$ $\dot{\alpha} v \tau \imath \theta \dot{\tau} \tau o v) ;$ they are each discussions of the use of antithesis.

47Marshall, 1 and 2 Thessalonians, 9-10.

48 Ibid, 10. 
offered in the letter, unless they all believe that exhortation is a characteristic of epideictic, as Lyons does. ${ }^{49}$ Further, they do not appear to address the question as to whether parænesis should be classified as a genre as such.

\section{A Letter sui generis}

Some scholars argue that 1 Thessalonians does not fit any of the classic categories and that it should be understood as being in some sense (at least at the time of writing) sui generis. Koester sees the letter as the first Christian letter. ${ }^{50}$ Thus:

when I Thessalonians was composed, no species or genre of the Christian letter existed, nor was there a pattern for the incorporation of particular sub-genres and forms, nor had the literary vocabulary and terminology for this type of writing been established. 51

Koester goes on to state that, although Paul seems to use the form of the private letter, we have no extant private letters with substantial thanksgiving sections or moral and eschatological discourses. He criticises the idea that 1 Thessalonians should be seen as parænetic, on the grounds that we do not have any extant parænetic letter which shares its formal characteristics. He accepts that traditional forms and traditional material are used, but sees both as being re-shaped by the Christian content of the letter.

${ }^{49}$ See notes 36,37 above.

50Helmut Koester, 'I Thessalonians - Experiment in Christian Writing', in F. F. Church and T. George (eds.), Continuity and Discontinuity in Church History: Essays Presented to G. H. Williams (Leiden: Brill, 1979) 33-44.

51Koester, 'I Thessalonians', 33. His conclusion still carries weight if it be accepted that Galatians preceded 1 Thessalonians, since 1 Thessalonians would still only be the second Christian letter and would be preceded by a highly controversial letter which would therefore hardly establish a genre. For the view that Galatians pre-dates 1 Thessalonians, see, e.g. Colin J. Hemer and Conrad H. Gempf (ed.), The Book of Acts in the Setting of Hellenistic History (Tübingen: J.C.B. Mohr [Paul Siebeck], 1989) 247-48; F.F. Bruce, The Epistle of Paul to the Galatians: A Commentary on the Greek Text (Exeter: Paternoster, 1982) 43-56 (esp. 53-55 on the relationship of Galatians and the Thessalonian epistles). 
Olbrich ${ }^{52}$ offers a rhetorical analysis of the letter from an Aristotelian perspective, but despairs of placing it within any one genre. He notes that some characteristics, according to Aristotle, 53 are common to the three Aristotelian genres; and that 1 Thessalonians contains characteristics of both deliberative and epideictic rhetoric. He proposes a new rhetorical genre, 'church rhetoric', following an observation of Johanson that Aristotle did not know the genre of the sermon, 54 and adding to it that there were considerable differences in world-view between Aristotle and the Christians. Olbricht goes on to focus the sub-set of the new genre appropriate to 1 Thessalonians as 'reconfirmational', which he sees as having links with parænesis, whilst also having differences with it too. The conclusion as to the sub-genre classification is arrived at on the basis of certain key texts $(2: 12 ; 3: 2 ; 5: 11)$ in which he sees Paul expressing the purpose of his letter, which is to announce the power of God, Christ and the Spirit in a way that brings the community to deeper commitment. 55

It is difficult to see in what sense Olbricht's work can be called 'Aristotelian', in that he rejects the three classic Aristotelian genres on the grounds that they are inappropriate to 1 Thessalonians. He goes on to use (with some profit) Aristotelian categories of analysis to understand the construction of the letter, but as to whether a genre 'church rhetoric' can be identified we must be at most agnostic in the light of Olbricht's failure to offer any other examples of the genre 'church rhetoric', let alone of the sub-genre 'reconfirmational church rhetoric'. In any case, Olbricht's description of this sub-genre sounds rather like epideictic, particularly with the emphasis on exhorting the audience to hold fast to a point of view in the present.

52Olbricht, 'An Aristotelian Rhetorical Analysis'.

53Olbricht (ibid, 225 n. 54) cites Aristotle Rhetoric 2.20.1: 'It remains to speak of the proofs common to all branches of Rhetoric, since the particular proofs have been discussed.'

54Johanson, To All the Brethren, 40, cited by Olbricht, 'An Aristotelian Rhetorical Analysis', 226 n. 59.

55Olbricht, 'An Aristotelian Rhetorical Analysis', 227. 


\section{Unresolved Questions}

In conclusion at this stage of the discussion, we may note two key questions, the answers to which will go towards determining our decision about the genre of 1 Thessalonians. First, what evidence is there that parænesis was seen as a genre in its own right? There remains a question as to what purpose the exhortation served, which makes it at least questionable whether we should accept parænesis as a genre proper. This would eliminate a number of the possibilities canvassed above, or at least require their modification.

Second, what evidence is there that Paul faced explicit opposition in the church at Thessalonica? To conclude that there were opponents would open the door to seeing the letter as judicial, for its focus would then be answering charges against Paul. On the other hand, to conclude that the evidence for opponents is at best inconclusive would point towards another rhetorical genre.

\section{Opponents in Thessalonica}

Is there a Pauline self-defence in 1 Thessalonians? Specifically, should we see 2:1ff. as responding either to criticism of Paul in Thessalonica by (some or all of) the Christians there or by opponents of Paul outside the church?

Many students of 1 Thessalonians consider that Paul is defending himself at various points in the letter, particularly in 2:1-12. Some see Paul's explanation in 2:17ff. of his failure to return as a significant exigence in the composition of the letter. Others view the presence of opponents or critics of Paulexternal or internal to the church-as a highly significant exigence. We shall need to consider these views carefully.

\section{Arguments for Opponents}

Bruce considers that Paul felt the need to explain his failure to return to Thessalonica following his rapid departure. ${ }^{56}$ This is the concern Bruce sees behind 2:17-3:10, where Paul reassures the Thessalonian Christians that he is concerned for them and

56F.F. Bruce, 1 \& 2 Thessalonians (Waco: Word, 1986) xxxvi. 
has tried 'again and again' (2:18) to visit them. However, Bruce does not espouse the conclusion that this explanation must imply the presence of opponents or critics in Thessalonica: this is the view of Schmithals, who sees 3:4 as referring to the fulfilment of Paul's prediction of personal attacks upon him which cast doubt on his trustworthiness. ${ }^{57}$ This reading is based on Schmithals' view that the 'we' of 3:4b has the same referent as the apostolic 'we' of 2:17.

However, there is a strong case for seeing the reference as being to the sufferings of the people of God in general, particularly given the context in 3:3. There Paul is speaking of the Thessalonians' suffering ('by these trials', ह่v $\tau \alpha \hat{\imath} \varsigma \quad \theta \lambda i \psi \varepsilon \sigma u v$

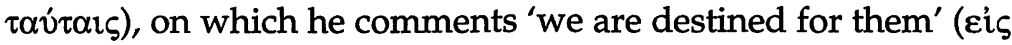

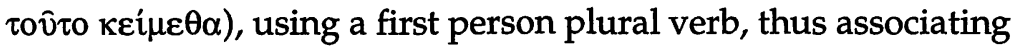
himself and his co-workers with the Thessalonians in the general destiny of the people of God to suffer. This is the more likely understanding, accordingly, of ' $w e^{\prime}$ in 3:4b.58

This makes Schmithals' reading of the situation, at least at this point in the letter, unlikely. Paul's explanation of his failure to return may simply be a way of reinforcing his concern for his converts in the pressure that they faced, a concern that he would have preferred to express face-to-face rather than by letter. Further, Paul may be anticipating possible criticisms here: there is no necessity to see actual critics or opponents of Paul in the Thessalonian church.

This leads us to a consideration of 2:1-12 itself, which is the major plank in the argument for opponents or critics in Thessalonica. Three variants in the 'Pauline defence' reading of this passage are notable.

Johanson ${ }^{59}$ believes that a major concern in 1 Thessalonians is to do with defending Paul's message, and he goes

57Walter Schmithals, Paul and the Gnostics (New York: Abingdon Press, 1972), 177-78.

58 See Ernest Best, A Commentary on the First and Second Epistles to the Thessalonians (London: A. \& C. Black, 1972) 136; Marshall, 1 and 2 Thessalonians, 91-92; Johanson, To All the Brethren, 105; Wanamaker, The Epistles to the Thessalonians, 130-31 for this view.

59Johanson, To All the Brethren, 58, 89-93, 164-65. 
on to argue that it would be impossible to defend the message without defending the messenger.

Johanson believes that the problem of the death of believers before the parousia provides the letter's major exigence. This, he argues, would naturally give rise to questions about Paul and his co-workers' sincerity and reliability. ${ }^{60}$ Paul's aim in 2:1-12 is therefore to deal with potential attacks and mistrust, rather than to reply to specific charges by the addressees. ${ }^{61}$ Johanson's understanding is that the sentiments in 3:6 express the writers' continuing goodwill towards the Thessalonian Christians, and that it would therefore be mistaken to see 2:1-12 as implying the presence of an antagonistic group. 62 Rather, the sense of agitation and the insistence present in the antitheses of 2:1-8 should be understood as displaying 'a perceptibly more than ordinary degree of pastoral intensity on the part of Paul'.63 The 'apology' of 2:1ff is thus to be seen as prophylactic or anticipative. 64

That said, Johanson does consider it possible that outsiders are a source for charges against Paul and his coworkers, for the persecution evident from the letter may well have included taunts against the founders of the Thessalonian church, alleging misconduct and impure motives. 65 Barclay concurs with this, writing 'that Paul was the target of at least slanderous abuse from non-believers in Thessalonica is the most likely implication of the painstaking personal defence he mounts in 2:3-12.'66 Moore suggests this kind of accusation

60Johanson, To All the Brethren, 58.

61 Ibid, 54.

${ }^{62} \mathrm{We}$ shall give further consideration below to Johanson's rejection of the presence of actual agitators against Paul and his colleagues.

63Johanson, To All the Brethren, 54.

${ }^{64} \mathrm{Ibid}, 164$. At this point Johanson is arguing in dependence on Malherbe, "'Gentle as a Nurse"', discussed below.

65 Ibid, 54.

66John M. G. Barclay, 'Conflict in Thessalonica', Catholic Biblical Quarterly 55 (1993) 512-30, esp. 513. Marshall, 1 and 2 Thessalonians, 61 argues similarly. 
would have come from either Jewish opponents or the pagan civic authorities. 67

Schmithals is notable for his advocacy of external opponents. ${ }^{68} \mathrm{He}$ understands 2:3-12 as a defence of the intention of Paul's preaching, and therefore of Paul's integrity. Schmithals believes there to have been gnostic opponents of Paul who were active in Thessalonica (and most other places), to which Jewett responds:

A major premise in the entire construction, however, is that gnostic missionaries from other churches are causing the difficulty in Thessalonica, a contention for which not a shred of credible evidence within the correspondence itself is available. 69

There are also scholars who consider that Paul is responding to actual criticisms from within the church. Jewett in particular argues that 2:1-12 should be seen as responding to an enthusiastic charge that Paul's visit had been 'in vain' (2:1) and had consisted merely in word, rather than in power (cf. 1:5). ${ }^{70}$ That is, Paul had failed to show himself to be a 'pneumatic' (Schmithals' word), because he had merely proclaimed the message without also demonstrating it. In response, Paul clarified his apostolic role in terms which differentiated him from that of 'spirit-filled, divinized leaders who flatter and exploit their devotees' ${ }^{71}$ Jewett believes there to have been criticism from some in Thessalonica that Paul's style of leadership was not more explicitly ecstatic. He further reads $5: 12-13$ as a defence of the (Pauline-appointed) congregational leaders against similar criticisms.

${ }^{67}$ Arthur L. Moore, 1 and 2 Thessalonians (London: Nelson/Oliphants, 1969) 32. J.E. Frame, The Epistles of Paul to the Thessalonians (Edinburgh: T. \& T. Clark, 1912) 9-10 argues similarly.

${ }^{68}$ Schmithals, Paul and the Gnostics, $142 \mathrm{ff}$.

${ }^{69} \mathrm{Ibid}, 148$.

70Ibid, 102. At this point at least Jewett concurs with Schmithals' analysis (in Paul and the Gnostics, 140).

71 Ibid, 169. 


\section{Response to Arguments for Opponents}

In response to these various arguments we may make a number of observations.

First, the antithetical style used in 2:1-12 does not necessarily mean that the views that are on the 'not...' side of the antitheses actually exist: opponents are an unnecessary hypothesis. Malherbe has demonstrated that an antithetical style could be used by the philosophers to teach about themselves, claiming that this style was appropriate to the parænetic use of historical examples. ${ }^{72}$ Lyons has further noticed that the antithetical style is used throughout the letter (he cites $1: 5,8 ; 2: 13,17 ; 4: 7,8 ; 5: 6,9,15)$ and it is clear that in at least some of these cases the contrary position need not be being affirmed by an opponent: 73

It is simply impossible to imagine that opponents claimed the reverse of the denials in 5:9-that God has destined us to wrath, not salvation; or in 5:15-that one should always repay evil for evil and not do good to one another. ${ }^{74}$

Both Malherbe and others who have followed him affirm that Paul in 2:1-12 is responding to criticisms not unlike those applied to wandering philosophers. ${ }^{75}$ On this understanding it would be entirely appropriate to use an antithetical style.

72Malherbe, 'Hellenistic Moralists and the New Testament', 283 n. 67, 290, 297-98. He cites particularly Dio Chrysostom Orations 32:11-12 as an example of this antithetical style. See also pseudo-Isocrates To Demonicus 9-15 in Abraham J. Malherbe, Moral Exhortation: A Greco-Roman Sourcebook (Philadelphia: Westminster Press, 1986) 125-27 for a good example of antithesis in parænesis, and Lyons, Pauline Autobiography, 105-12; Raymond F. Collins, Studies on the First Letter to the Thessalonians (Leuven: Leuven University Press, 1984) 183-185. Collins cites as examples of philosophers who used antithesis in a fashion similar to Paul, Heraclitus, Democritus, Gorgias and Dio Chrysostom. See also Aune, The New Testament in its Literary Environment, 206, discussed above.

73Lyons, Pauline Autobiography, 184, esp. n. 25.

74Lyons, Pauline Autobiography, 184.

${ }^{75}$ Malherbe, "'Gentle as a Nurse"'. See also Koester, 'I Thessalonians', 3344, 41; Boers, 'The Form-Critical Study of Paul's Letters', 150; Collins, Studies on the First Letter to the Thessalonians, 185; Johanson, To All the Brethren, 53, 164-65 (who also draws attention to OT and Jewish parallels, 
In a different vein Winter argues that Paul may have faced a problem in Corinth (Paul's likeliest location when 1 Thessalonians was written) which prompted him to write to the Thessalonians in a manner designed to head off the potential for that problem recurring in Thessalonica. ${ }^{76}$ This problem Winter identifies with the Corinthians' expectation that Paul would take a similar approach to the professional orators:

Paul had no desire for his relationship to be hindered by the powerful, secular perception of a disciple to his orator or sophist. His second entry to Thessalonica or that of any other Christian teacher must not be identified or compared with orators because of the deleterious effects it would have on relationships and the integrity of the teaching ministry with the Christian community. 77

Accordingly, Winter argues that the antithetical nature of 2:1-12 should be understood as Paul contrasting himself, not with opponents, but with professional orators who sought the very things which Paul denied that he had sought, namely glory, praise and financial gain-and that they sought these things using deceptive methods including flattery.78

Winter further notes that Paul ends 2:1-12 with a strong statement of his purpose, namely that the Thessalonian Christians should walk worthily of God, and returns to this in explaining his present concern $(3: 10 b-13)$ that they should continue in the way which he demonstrated when with them. Thus Paul is offering a model of Christian living to the Thessalonian Christians, and not only a model of Christian leadership.

This links to the use of the language of imitation in the letter $(1: 6 ; 2: 14)$, which is unusual, in that the Thessalonians are the only Christians in the Pauline corpus who are told that they

such as the description of the Teacher of Righteousness in $1 \mathrm{QH}$ vii.6-25); Wanamaker, The Epistles to the Thessalonians, 91.

76Winter, 'Entries and Ethics', 71.

77 Ibid.

78Ibid, 67-68. 
already imitate Paul, rather than being called to imitate him. ${ }^{79}$ This points in two further directions, namely the strong positive relationship that is indicated between Paul and the Thessalonian Christians here and elsewhere in the letter, and the philophronetic function of the autobiographical material in 2:1-12; that is, that Paul writes in such a manner at least partially to reassure the Thessalonians of his continuing care and concern for them.

Second, the text of 1 Thessalonians bears witness to good relationships between Paul and the Thessalonian Christians.80 Paul states that he is pleased with their progress in the face of persecution (2:14), 81 with the example of love that they demonstrate $(1: 3 ; 4: 9-12)$, and with their positive remembrance of Paul himself (3:6). 82 There is neither strong rebuke or criticism of the church nor suggestion that the Thessalonian Christians had significantly departed from true Christian belief or practice. Rather, Paul is encouraging them along a path which they are already pursuing-hence his encouragement of them in both 4:1 and 4:10. To be sure, Paul was able to offer assistance by adding to their present faith and knowledge (3:10), as would have been the case with every Christian community of the time, but this does not necessarily imply criticism of the Thessalonian Christians. Moffatt summarises aptly: 'Their faith required completion rather than correction.' 83

${ }^{79}$ Contrast 1 Cor. 4:16; 11:1; Gal. 4:12; Phil. 3:17; 2 Thes. 3:7, 9. For discussion, see Lyons, Pauline Autobiography, 190-91; Malherbe, 'Exhortation in First Thessalonians', 246-47; Malherbe, 'Hellenistic Moralists and the New Testament', 267-333, 290; Elizabeth A. Castelli, Imitating Paul: A Discourse of Power (Louisville: Westminster/John Knox Press, 1991) 89-117, esp. 90-95, where she discusses the two texts in 1 Thessalonians.

${ }^{80}$ See Best, A Commentary on the First and Second Epistles to the Thessalonians, 15 for many of the points that follow.

81So also Wanamaker, The Epistles to the Thessalonians, 60.

82Johanson, To All the Brethren, 52 draws particular attention to this verse, arguing that for Paul to write as he does in 3:6 would be an ironic insult to the Thessalonian church, if the reality were that Paul was defending himself against charges, arising from the Thessalonian Christians, of insincerity, dishonesty and self-interest in 2:1-12.

83James Moffatt, An Introduction to the Literature of the New Testament (Edinburgh: T. \& T. Clark, 1918) 69. 
It is these places in the text which Donfried has correctly seen to point towards the paracletic function of the letter.84

Third, Lyons has persuasively argued that the autobiographical material in 2:1-12 should be seen as having a parænetic function: in these verses Paul is offering his own practice and conduct as a moral example of Christian behaviour. ${ }^{85}$

Lyons observes that in 1:4ff. two proofs are offered of the divine election of the Thessalonian Christians: Paul's ethos as a preacher of the gospel (1:5) and the perseverance of the Thessalonians in the face of persecution (1:6ff.). The first of these proofs is taken up in 2:1-12 and the second in 2:13-16.86 Lyons observes several connections between 1:2-10 and 2:1-12 which reinforce this possibility. ${ }^{87}$

He goes on to discuss a number of aspects of Paul's exemplary ethos which become explicit in his parænesis, namely his encouragement or exhortation (2:3, 11-12; 4:1, 18; $5: 11)$; his holy and blameless moral conduct $(2: 3,9-12 ; 4: 1-7$; $5: 22-23)$; his sense of responsibility to please God $(2: 4,15 ; 4: 1)$; his brotherly love and constant friendship, both whilst with and whilst parted from the Thessalonian Christians (2:5-8, 17$18 ; 3: 6,10,12 ; 4: 9-12 ; 5: 15)$; his manual labour and self-support $(2: 8-9 ; 4: 9-12 ; 5: 12-14)$; his constant prayers of thanksgiving $(1: 2$; $2: 13 ; 3: 10 ; 5: 17-18)$; his joy in the midst of affliction $(1: 6 ; 3: 9-10$; $5: 16-18)$; and his eschatological hope $(1: 10 ; 2: 19-20 ; 3: 13 ; 4: 13-$ $5: 11) .88$ It is thus apparent that many significant points of Paul's

${ }^{84}$ Donfried, 'The Theology of 1 Thessalonians as a Reflection of its Purpose'; Donfried \& Marshall, The Theology of the Shorter Pauline Letters, 5. 85Lyons, Pauline Autobiography, 189-221.

86 Ibid, 191. Best, A Commentary on the First and Second Epistles to the Thessalonians, 88 concurs with this analysis: 'As in 1.2-10 there is a movement of thought in 2.1-17 from the activity of the missionaries (2.112 , cf. 1.3-5) to the response of the Thessalonians (2.13-17, cf. 1.6-10).' Similar is J.B. Lightfoot, Notes on the Epistles of St Paul (London/Peabody: Macmillan/Hendrickson, 1895/1993) 18.

87 Ibid, 191-92. He cites the use of the conjunction $\gamma$ ó $\rho(2: 1)$, the terminology of mutual knowledge and memory $(1: 3,4,5 ; 2: 1,2,5,9,11)$, both of the work done $(1: 5 ; 2: 9)$ and of each other's behaviour.

88Summarised in Lyons, Pauline Autobiography, 218-19. 
ethos become explicit points of exhortation to the Thessalonian Christians elsewhere in the letter.

Malherbe has also argued that 2:1-12 should be seen as parænetic, on the basis that 'A major part of ancient parænesis was the offering of a model to be imitated.' 89

Wanamaker, whilst agreeing with the thrust of Lyons and Malherbe's views, suggests that a subsidiary motivation in the autobiographical material was to reassure the readers of the writers' continuing care for them, particularly in the light of possible misunderstanding of Paul's failure to visit again. 90

Fourth, there is a lack of any specific charges against Paul. Hughes' observation is apposite:

It is possible to read 2,10 as a defense against either specific charges or suspicions concerning Paul. However, since no such charges are taken up in the three-part probatio, and since Paul in the narratio consistently praises himself and then praises the Thessalonians' positive response to him, it does not appear that Paul was defending himself against charges. ${ }^{91}$

Fifth, Lyons, having listed the points from Paul's ethos that are taken up explicitly in exhortation in the letter, wisely warns against 'mirror-reading' these exhortations to deduce specific moral deficiencies in the Thessalonian church. 92 However, as he goes on to point out, we may therefore have here an indication of what Paul considers to be 'ethically momentous', that is, we may here be given insight into key themes of Paul's general moral exhortation and encouragement. If so, this is a valuable piece of information indeed.

In the light of the considerations above we may conclude that there is no necessity for the background to 2:1-12 to be specific charges against Paul and his colleagues, especially from within the church. We may accept that outsiders might have vilified the missionaries, as part of the persecution which

\footnotetext{
${ }^{89}$ Malherbe, 'Exhortation in First Thessalonians', 240-41. He cites Seneca Epistles 6.5-6; 11.9-10; 95.72.

90Wanamaker, The Epistles to the Thessalonians, 61.

91Hughes, 'The Rhetoric of 1 Thessalonians', 101. He identifies the probatio as 4:1-5:3 and the narratio as 2:1-3:10.

92Lyons, Pauline Autobiography, 219.
} 
Paul mentions, whilst remaining agnostic as to whether Paul is responding to specific charges from outsiders. In the light of the evidence assembled, it seems more likely that the antithetical style of 2:1-12 is adopted as a way of expanding and clarifying Paul's teaching, in line with the practice of other ancient authors. 93 This also fits better with the evident good relationship between Paul and the Thessalonian Christians.

\section{Conclusions on Rhetorical Genre}

In the light of the above discussion, we return to the question of the rhetorical genre of the letter. We have established that the case for a Pauline self-defence in the letter is at best inconclusive, and have offered alternative explanations of the phenomena in the text (such as antithesis) which have given rise to theories of opponents in Thessalonica. This makes it unlikely that the letter should be classified as forensic rhetoric.

The evidence of the work of Burgess is that parænesis is not a rhetorical genre proper, but may be a feature of both epideictic and deliberative rhetoric. ${ }^{94}$ The key question we need to answer, in deciding whether 1 Thessalonians fits either of these genres, then, is whether it manifests the major characteristics of that genre, not whether it is parænetic or contains parænetic elements.

In any case, there may be some confusion of rhetorical and epistolary classifications in speaking of a 'parænetic letter'. The ancients had schemes of classification of letters, but there was little written on letters in the context of the rhetorical handbooks. The validity of considering 1 Thessalonians using the tools of ancient rhetoric stems from the nature of this letter, which was effectively as a speech by Paul in absentia, since the letter would be read aloud to the assembled company of Christians in Thessalonica. 95 Thus this letter can be classified using rhetorical genres, but this is a different exercise to

${ }^{93}$ Aune, The New Testament in its Literary Environment, 206.

${ }^{94}$ Burgess, Epideictic Literature, 228-34.

95See my article 'Rhetorical Criticism: An Introduction'. 
determining the precise function of the letter, which was the method of classification of letters employed by the ancients. 96

Returning to the question of rhetorical genre, we may note that Aristotle observes:

In deliberative oratory, narrative is very rare, because no-one can narrate things to come; if there is narrative, it will be of things past, in order that, being reminded of them, the hearers may take better counsel about the future. This may be done in a spirit either of blame or of praise; but in that case the speaker does not perform the function of a deliberative orator. ${ }^{97}$

Since it seems clear that the narrative in 1 Thessalonians is, at least in part, praise of Paul's and the Thessalonian Christians' conduct, this must incline us towards seeing the letter as epideictic.

Moreover, the evidence discussed above suggests that the letter may be regarded as epideictic, in that a highly significant element within it is praise and thanksgiving, which are characteristic marks of epideictic. This conclusion is qualified by Chase's observation that epideictic was not a watertight compartment in ancient times. Chase notes, for example, that an epideictic oration in classical thought need not be limited solely to praise or blame: 'The ancient orators were prone to blend several functions in a given oration.' 98 This, in combination with the understanding that epideictic could contain parænetic elements, allows us to view the letter as epideictic, since its focus is praise of the Thessalonians for their maintenance of faith in the present in the face of pressure to the contrary, along with encouragement to continue in that faith. 99

\footnotetext{
96See, e.g., the classifications found in pseudo-Libanius and pseudoDemetrius: texts in Malherbe, Ancient Epistolary Theorists; discussion in Aune, The New Testament in its Literary Environment, 160-74.

97 Aristotle Rhetoric 3.16.11 (italics mine).

98J. Richard Chase, 'The Classical Conception of Epideictic', Quarterly Journal of Speech XLVII (1961) 293-300, esp. 300 n. 39. He further observes that praise or blame, widely understood to be the distinguishing mark of epideictic, may be properly used in deliberative and judicial rhetoric.

${ }^{99}$ This article is a revised form of part of a paper presented at the Tyndale Fellowship New Testament Study Group in July 1994. I am very grateful for the stimulating and helpful questions and comments of those present.
} 